\title{
Historical Analysis of Research and Development Institutions in Indonesia
}

\author{
Ihsana El Khuluqo ${ }^{1,}$ Kuncoro Haryo Pribadi ${ }^{2}$ \\ ${ }^{1}$ Vocational Education Progra,. Universitas Indonesia \\ ${ }^{2}$ Muhammadiyah University of Prof. Dr. HAMKA, Indonesia \\ *Email: ihsana_khuluqo@uhamka.ac.id
}

\begin{abstract}
A well-educated workforce is crucial for Indonesia as it engages with the Association of Southeast Asian Nations (ASEAN) Economic Community because the country must foster the ability to compete in an increasingly fluid and competitive regional landscape. However, Indonesia's international standard research output has been inadequate. Although the country has over 3,000 universities, these institutions vary widely in their quality and face a shortage of qualified academics with doctoral degrees on their staff. It is commonly known that Indonesian scientists living and working abroad are very reluctant to return to Indonesia due to the lack of material and non-material rewards they are offered in their home country. The State Budgeting and Expenditure allocation on Research and Development (R\&D) evinces a pattern of exponential decline from 1969 to 2009. The total R\&D budget ratio assigned by the Jokowi administration is still the same as previous years at 0.8 percent. Using the new institutionalism perspective offered by Charles E. Bidwell, the current study found that the R\&D sector is not accorded priority by either the public or the government. As the executor, the government's development plan is grounded on issues raised by the community (decentralization). However, the community itself is still fueled by a consumerist egotism and is thus struggling at the ideological, prestige, and psychological levels.
\end{abstract}

Keywords: institution, funding, research and development, priority, and national development

\section{Introduction}

As Indonesia engages increasingly with the ASEAN Economic Community, the development of a welleducated workforce is crucial for it to be able to compete in an increasingly fluid and competitive regional landscape. Although Indonesia has over 3,000 universities, these institutions vary significantly in quality and evince a lack of qualified academics with doctoral degrees on their staff. Unsurprisingly, Indonesia's international standard research output has been inadequate (OECD, 2010). While it is difficult to place a benchmark across countries with regard to the knowledge sector, several international comparisons indicate that Indonesia's knowledge generation is well below other countries that show a comparable economic standing. For instance, Scimagojr (2016) reported that Indonesia ranks fourth out of the10 ASEAN countries in the category of works cited and the number of published scientific research papers.

To a certain extent, research intensity correlates with the per capita Gross Domestic Product (GDP) and the Human Development Index. This argument holds that economic growth should allow for increased investment in higher education and quality research. However, Indonesia's research intensity is still low vis-à-vis its national GDP in comparison to other ASEAN countries such as Thailand, Singapore, and Malaysia, all of which have a lower GDP than Indonesia.

In 2016, the GDP of Indonesia amounted to USD 932,259 million (The World Bank, 2016), and was ranked at the top of the list of the ASEAN countries. However, in the context of academic publications, Indonesian scientific journals were only able to publish 2,928 scientific papers in 2016. In comparison, Thailand, Singapore, and Malaysia published more scientific papers even though the revenues they accrued were only half the income generated by Indonesia. Indonesia also ranks low in the number of citations for its research papers.

Such studies and their methods of calibration are extremely open to scrutiny as the number of publications is not a measure of the quality of research being produced. In addition, the parameter of number of citations by peers is flawed because it is highly influenced by the availability of a paper in English and therefore, certain 
countries gain an unfair advantage. Only a small part of the full picture may be seen by focusing on rankings and ratings as the defining measurement of Indonesian scientific rigor.

In a larger perspective, Indonesia is home to a number of highly reputable universities whose graduates contribute to and lead research in the country. Indonesians living and working abroad also participate in scientific research around the world: approximately 2,000 Indonesian scientists work at various prestigious international institutions in countries ranging from Singapore to Japan to the USA. Some notable names among these researchers include Dr Khoirul Anwar, the inventor of 4G/LTE communications technology, who now works as an assistant professor at Japan Advanced Institute of Science and Technology; Yow-Pin Lim, MD, PhD, who is currently assistant professor at Brown Medical School and is also a research oncologist at the Department of Medicine at Rhode Island Hospital; Dr Mohammed Reza, a researcher in Sweden; Professor Ken Soetanto of Waseda University, Japan; and Andrivo Rusyidi of the National University of Singapore (GBGI, 2015).

While the presence of Indonesian scientists abroad accords a view of the full picture of the Indonesian educational sector, it also highlights critical problems with regard to Indonesian education and scientific exploration, especially in the areas of higher learning and R\&D.

It is common knowledge that Indonesian scientists living and working abroad are very reluctant to return to Indonesia because of the perceived lack of rewards, both material and non-material, they are offered in their home country. For instance, the average salary offered to a professor in Indonesia is USD 601 per month. This salary ranks seventh among ASEAN countries, below Vietnam, Malaysia, Thailand, Brunei, and Singapore, where salaries of professors range between USD 658 and USD 8,000 per month (SalaryExplorer, 2017).

Similarly, the lack of government funding for research is also a stumbling block for higher education in Indonesia. In fact, Indonesia is placed at the bottom of the scale in this category. According to the World Bank, the Indonesian government's budget allocation for the R\&D sector is only $0.08 \%$ of its GDP, a percentage significantly lower than the expenditure assigned by neighboring countries such as Singapore (2.19\%) and Malaysia (1.26\%) (The World Bank, 2015). The paucity of research funding coupled with more career opportunities and better facilities abroad creates a perfect set of circumstances for researchers to leave Indonesia.

The above situation creates a negative image of the scientific sector in society. Research is considered a nonpromising career path for the nation's youth. The implications of this adverse perception can be observed through closer scrutiny of the Indonesian education sector. According to the Minister of Research, Technology, and Higher Education (MENRISTEKDIKTI) Mohammad Nasir (2017), there are 230,633 lecturers in Indonesia. Of them, 22.99 percent hold an undergraduate degree, 58.33 percent have qualified for a post-graduate degree, and only 11.36 percent or around 26,199 lecturers have earned a doctoral degree. In other words, there are only 143 Indonesian doctoral degree holders for every million Indonesians. This figure is significantly lower compared to other Asian countries such as Malaysia, India, and Japan, which respectively have 509, 1,410, and 6,438 doctoral degree holders per million inhabitants.

This lack of focus on the education sector seemed to be on the brink of change when Jokowi stated during his presidential election campaign that education would be among his regime's top priorities. Indeed, since the beginning of its tenure, the Jokowi administration has made some changes in the world of Indonesian scholarship. Notable changes ushered in by the Jokowi administration include increments to the education budget, the unification of higher education affairs under the Ministry of Research and Technology (KEMENRISTEKDIKTI), and the revision of Law no. 13/2016 governing patents and royalties on patents for researchers.

However, the funding for the R\&D sector is yet to be touched. The R\&D budget has, so far, never seen a significant increase regardless of the government in power. Indeed, the data reflect the stagnant status: for instance, a Lembaga Ilmu Pengetahuan Indonesia (LIPI, or the Indonesian Institute of Sciences) publication demonstrated that the ratio of the R\&D budget to Anggaran Pendapatan dan Belanja Negara (APBN) calculated from 1969 to 2009 shows a declining exponential pattern. This configuration illustrates that the government's attention to R\&D was quite high at the beginning of the country's development stage and that it subsequently dropped drastically, reaching a near-stagnant state. APBN has increased 4,000 times while R\&D has only increased 420 times (Risbang Dikti, 2016).

Some studies (Maass, 2003; Strehl, Reisinger, \& Kalatschan, 2006; Tahmooresnejad \& Beaudry, 2015; and Payne \& Siow, 2000) have confirmed that institutional management and funding reforms correlate positively with the quantity and quality of scientific publications.

However, it appears that this finding has not been taken seriously by the Indonesian government, and there is still no rigid policy for its implementation. Thus, research aimed at assessing government and community preferences for the R\&D sector must be conducted. Such studies assume particular importance given the chronic problems and the lack of investigations on the Indonesian government's preferences in the R\&D sector. Additionally, it is expected that the present study will be a stepping stone for further research aimed at proposing an effective recommendation for the Indonesian government to address the chronic problems of R\&D in Indonesia. 


\section{Research Questions}

Based on the brief description tendered above, there are at least two research questions that can be used as a guide to the achievement of an unbiased analysis in the next segment of the paper:

1. Why is such a small proportion of the state budget of Indonesia marked for the R\&D sector?

2. How do the Indonesian government and Indonesian society at large view the R\&D sector?

\section{Theoretical Framework}

Since the 1990s, a theoretical perspective known as "new institutionalism" (Bidwell, 2006) has captured the imagination of scholars working in academic fields that contribute to educational research and policy analysis. Such disciplines include sociology, political science, economics, and organization theory. Applications of new institutionalism to the study of education have been scattered and diffuse despite the promise of the theory (Bidwell, 2006).

The early groundwork for the analysis of social institutions was laid by the European classical thinkers including Montesquieu, Tocqueville, Marx, Weber, and, in particular, Emile Durkheim. For Durkheim (1901, 1912), institutions arise out of joint human activity and are constituted of sets of symbols both cognitive (knowledge and belief) and moral ("moral authority"). These symbols fix action into patterns that extend beyond the behavior of any individual. Thus, Durkheim treats institutions as emergent, taking form in the life cycle of human groups. Once formed, institutions are profound external sources for the regulation of human conduct and for the stabilization of social structures.

Durkheim (1911) analyzes the mechanisms that brought the University of Paris into being in L'Evolution Pédagogique en France (translated into English as The Evolution of Educational Thought). Three aspects of Durkheim's analysis are particularly noteworthy. First, the institutionalization of the university was set in motion by the action of both individuals and groups: the interests of students on the one hand and of the group of teachers and of the papacy, on the other. Both material and ideal interests were at stake, and these interacted to direct and propel the actions of the players.

Second, both appropriation and invention were involved in the structural and normative development and in the elaboration of patterns of activity. For example, the structural development of the University of Paris emerged from the appropriation of guild organizations and their governance, as well as from the invention of faculties and colleges. The norms that regularized the daily circle of university life and the contents of the university's curricula were also partly appropriated and partly invented.

Third, the university survived because it was adequately adapted to its environment: it suited the desires of students and their families, it was nourished by the economic means of the increasingly prosperous commercial classes, and it served the interests of the papacy and subsequently the developing state. In fact, it was the good fit between what was demanded and what the teachers could supply that became the prime basis for the developing power of the universities. In this sense, institutions create power.

William Graham Sumner, writing in Folkways (1906, 53-54) at around the same time as Durkheim, says that

"[a]n institution consists of a concept (idea, notion, doctrine, interest) and a structure... The structure holds the concept and furnishes instrumentalities for bringing it into the world of facts and action in a way to serve the interests of men [sic] in society."

He emphasizes relationships more as a means of realizing what is symbolized than as matrix out of which the symbols emerge. Sumner's ideas about social institutions center around symbols and bring to light the interests - particularly, the concerns of powerful actors - that motivate actions that in turn, drive the institutionalization of relationships. Thus, unlike Durkheim, Sumner emphasizes enactment even though he says that institutions can be either "crescive" (i.e., emergent) or enacted. In fact, he contends that no social structure, crescive or enacted, can survive to full institutionalization unless it serves the interests of a powerful elite.

At the same time, Sumner is careful to highlight that institutional formation is subject to the discipline of cultural selection. In other words, if they are to find institutional expression, the interests are pursued by powerful actors must be in accord with the society's core values and normative specifications (in Sumner's terms, "the mores"). Thus, institutionalization is a matter of legitimacy as well as of power.

Several important points later emerged from the two ideas described above and became the basis for the development of new institutional perspectives in education. They are: 
1. The treatment of institutionalization as a process driven by political mechanisms; in particular, the use of power by the elite classes to realize their interconnected ideal and material interests.

2. The discipline of institutional selection according to environmental fitness (the mores).

3. The use of natural histories to reveal the action of these mechanisms and environmental constraints in institutionalization.

\section{Methodology}

The present paper reports preliminary descriptive-analytical research that is conducted using the qualitativehistorical approach as the basis for analysis. The data used in the research were collected from secondary sources such as books, journals, or other relevant publications related to the theme of the paper. Due to its characteristics, Charles E. Bidwell's approach to new institutionalism is considered to be the most appropriate analytical tool to achieve the purpose of this paper. Therefore, this paper seeks to gain an understanding of the interests, preferences, and the level of environmental needs (especially those of the Indonesian government and society) of the R\&D sector in Indonesia through an examination of the historical aspect of institutionalization.

In congruence with the framework proposed by Bidwell, the main analysis section of the paper will be divided into two sub-sections, followed by the conclusion and the recommendations for future research endeavors.

The first section of the discussion will highlight the political mechanisms, specifically the use of power by the elite classes. These mechanisms aid the scientific sector's realization of the interconnected ideals and material interests of empowered sections of Indonesian society. The present discussion is closely related to the allocation of state expenditure, which is further densely connected to the national development plan. Hence, this study scrutinizes the prioritization of state expenditures under every administration since the proclamation of Indonesia's independence from colonial rule. In simpler words, the ensuing section will analyze and describe the priorities of the national development plans adopted by successive Indonesian governments.

The segment that follows takes environmental fitness into account in investigating the institutional selection during the course of the institutionalization of the R\&D sector in Indonesia. In so doing, it contemplates both the cultural aspect and the policies established by each Indonesian government. Finally, recommendations are outlined for both the Indonesian government and for future research projects.

\section{Discussion}

\subsection{National Development Priorities: Soekarno to Jokowi}

Indonesia's independence occurred in 1945. Since then, the advancement of science and technology has featured as one of the priorities in the Indonesian national development agenda. However, this sector has never become a primary concern for Indonesian policy makers when it comøs to implementation. Rather, in the time that has passed since Indonesia's independence, policy makers have focused mostly on issues pertaining to the economy, the social sector, politics, and welfare. During Soekarno's leadership, also called the Old Order, the main and obvious attention was devoted to the correction of the ill-effects of Indonesia's colonial past on its economy, its politics, its social sector, and the welfare of its people. The issue of building Indonesia into a nation that could sustain itself without foreign aid or assistance was often raised. However, the New Order led by General Soeharto also faced the same problems as the previous administration (Yazid, 2014).

Subsequently, Indonesia's development priorities and patterns underwent drastic changes as the nation stepped into its post-reform. The centralized development pattern with its focus on the economic sector was radically transformed into a decentralized configuration that concentrated on contemporary issues. For instance, the middle range national development plan of 2004-2009 considered international terrorism and the enhancement of national defense systems to be important issues; the plan of 2010-2015 attended to bureaucratic reform, and the current administration is faced with the problem of the increasingly unclear character of the nation and its states.

Despite this change, Indonesia's development priorities are still confined to domestic improvement. The country does not yet establish regionally or internationally oriented development priorities. The Old Order accorded precedence to improvement over the colonial period; the New Order allotted primacy to the enhancement of the legacy of the Old Order; the current post-reformation administration renders a correspondingly similar agenda of importance. In other words, every subsequent government tries to appropriate and to overtake the developmental achievements of past administrations and prescribes a take-off (further development) stage for its national development priorities.

The above explanation highlights the existence of two different political contexts that determine the developmental priorities of Indonesia. The first includes both the Old Order and the New Order. During these re- 
gimes, the development priorities were vested completely in the hands of the government (or the leader). The administrations of both the old and the new orders were characterized by untrained human resources and the desire to survive in the aftermath of independence. The small number of captive societies that existed at the time ultimately elicited a governmental character that was similarly centralized. The two orders were only distinguished in the methods they adopted. Sukarno's Old Order tried to lead the nation through his personal charisma toward the dream of a self-sustaining economy that did not require foreign assistance. Subsequently, in the New Order, Suharto inherited almost the same conditions and attempted to lead the nation to further economic development by exerting a coercive power on society which was still considered to be incapable of its own improvement.

A break from this pattern began to take shape in the post-reform period that began in 1998. People from the grass root level started getting a greater say in the shaping of the country's developmental priorities. Since this time, the central government's deep involvement in every aspect of Indonesian life has been reduced to a great extent. However, even though the pattern of development in the post-reform era is decentralized, the theme of development is the same as the previous eras: to improve on the legacies of the previous administration. The emergent issues of the post-reform period took on heterogeneous colors in the euphoria of democracy. Consequently, the focus of national development has become unsteadily linear and very pragmatic. It depends on the revisions of actions taken by the previous administration and on issues that arise in public discourses. For instance, human rights became prioritized because of the New Order's repression of the people, Terrorism became highlighted in 2004, and bureaucracy reform was driven by the spirit of reformation era. Topics such as ethnicity, religion, and Indonesian identity are also examples that echo issues that have surfaced in post-reform society.

However, although control over development priorities was democratized, the scientific sector in Indonesia, especially R\&D, never become apparent as an issue of import in public discourse. Why did the advancement of science and technology not emerge as a societal concern in Indonesia? To explore the issue further, public preferences will be discussed in more detail in the sub-sections that follow.

\subsection{Colonial Heritage: The Indonesian Cultural Identity and the Perspective of Development}

Post-colonial thinkers believe strongly that every country previously colonized by foreign forces (usually, the developed countries of the West), undergoes various obstacles in determining the course of its development. This process begins when the independence that is sought and fought for is achieved. Scholars have also asserted that the effects of colonialism make subjugated nations believe that their culture, religion, customs, and traditions are inferior to those of the West. Additionally, a mental fragmentation results from the efforts of the colonized to identify with the Empire despite the impossibility of equating with the colonizer. The colonized thus suffer from a sense of dislocation, placelessness, and loss of identity (Sharmin, 2010).

The social distance between the colonizer and the colonized is vast. It causes the people of colonized nations to live entrenched in local traditions full of myths about the supremacy and the invulnerability of feudal local leaders. The social structure of a colonized country results from the colonizer's imposition of a societal configuration in the colonized country.

Under the yoke of colonialism, local kings would often obtain power to preserve the position of the colonizer. Although strategies varied, colonizers legitimized the existence of local kings who supported their interests. At the same time, the myriad traditions and value systems developed by these same kings and sultans became value standards for the society and people who viewed them as being developed by their local ruler as a general set of principles that governed their daily lives (Sairin, 2011).

\subsection{Early Proclamation Period}

Indeed, the observations of post-colonial thinkers mentioned above hold true in Indonesia's case. The local population of Indonesia occupied the lowest rungs of the social ladder during colonial rule, and the potential for upward economic and social mobility was largely restricted to the middle class. Drastic class changes among the locals, though very rare, were not unheard of, but could only be achieved by a handful of people who had the willingness and the drive to shatter the limits set by the colonizer.

Boeke (1954), an expert in Dutch economics, stated that the export market developed by the Dutch colonial administration in Indonesia did not offer any socio-economic benefits to the indigenous people. The colonial era in Indonesia was thus marked by economic dualism: the capitalist economy built by the Dutch through the development of export commodities did not involve the people's economy that was run by the Indonesians. Furnival (1948) also stated that the Dutch East Indies economy indirectly formed a plural society within the colonized society. While white people occupied the upper echelons of this social order, migrants from the Far East, espe- 
cially Chinese, occupied the middle. Indigenous Indonesians, meanwhile, were relegated to the lowest rungs of the social ladder.

Unsurprisingly, this unfair treatment of the local population culminated to a turning point and ushered cultural change into Indonesia. The discriminatory practices of the colonial era resulted in Indonesians harboring very negative views about the Western world as represented to them by the Dutch masters, especially with regard to the political and economic policies. The idea of nationalism was ignited and was fueled by some young educated people of the country yang pada akhirnya melahirkan kemerdekaan Indonesia pada tahun 1945.

After Indonesia's independence and under the leadership of Soekarno, the general antipathy against the Dutch resulted in the creation of a nationalization policy that affected every Dutch-owned company in Indonesia. However, the plan did not go well due to the chaotic circumstances and the untenably untrained quality of Indonesia's human resources. A large part of the failure of nationalization may be attributed to the inability of poorly-trained indigenous people to understand the complex management systems of foreign companies. However, despite the failure, Soekarno managed to blame the fiasco on the Dutch and on the Western world because of his charismatic leadership.

Demographically dominated by un-educated people, Indonesian society may be likened to a domesticated animal that follows the lead of its master. Soekarno's personal charm, his oratorial skills, and his strong antiDutch and anti-West rhetoric were further encouraged by his communist orientation. He blamed the West and removed everything that was considered to be influenced by Western culture from the life of Indonesians. While English was still allowed, Dutch ceased to be taught in schools, and young Indonesians were deprived of the opportunity to learn from books and documents written in Dutch. Traditional knowledge, which was the staple of education in the lower strata of society, was far below the international standard of the time and was hence inadequate.

\subsection{Soeharto's New Order Period}

After Soekarno relinquished his chair to Soeharto in 1966, the anti-West movement promoted by Soekarno immediately reversed course. Soeharto overcame the political and economic crisis that befell Indonesia by steering the country closer to the Western world. In the academic arena, Soeharto's New Order established over 20 state universities across the Indonesian archipelago, allowing the country's subjects greater access to higher education. However, the education policies under the Soeharto administration subjected universities to rigid centralized control by the government and curtailed the autonomy and academic freedom of the universities. The government was not really interested in funding independent social research and created an environment that discouraged the undertaking of research that could be deemed critical of government policies.

It is vital for institutions of higher learning to be able to produce high quality and independent policy knowledge; it is equally important to develop an audience that is able and willing to use this body of knowledge. Under the New Order, the main development function of sub-national governments was to execute national policies, not to develop their own policies and programs based on local assessments. In countries such as Colombia, India, or the Philippines, local officials and administrations were sufficiently accountable for the promotion of autonomous policy decisions, tailored assessments, and the undertaking of feasibility studies by universities, think tanks, and consulting groups. In contrast, Indonesian legislators and administrators were accorded scant discretionary powers and thus did not develop procedures for commissioning or reviewing high quality and locally generated research. Additionally, the New Order government, for the most part, did not encourage local participation and debate on policy issues, as has been seen in other centralized countries such as China. There were few reasons for universities or independent institutes to develop systems for quality control, policy responsiveness, or applied research given the deficiency of accountability and the lack of demand for independent research.

It should be noted here that the success of the pro-West development program during the Soeharto administration improved the general well-being of society. However, only a few people, the Indonesian elite classes, were really able to enjoy the fruits of prosperity. The majority of the people were still trapped in poverty. The 1998 economic crisis ended in the reformation, which was the culmination of the people's compensation for the New Order's oppression and restraints. It also marked a new chapter in the development of a markedly Indonesian culture and identity.

\subsection{Post-Reformation Era}

The post-Soeharto administration also chose a policy that opened Indonesia to the outside world. Advancement in information and communications technology aided the process and Indonesia began to emerge as a market for Western products. The processes of globalization also brought new ideas to Indonesia, including the 
concepts of democracy and human rights. However, various problems occurred when these ideas were implemented in Indonesian society, particularly because the new ideas often came directly from the West and were opposed to the local culture.

A particular kind of cultural opposition emerged along with transformations in political, economic, and social systems brought about by Western modernity through the globalization process. People within these streams started to create a model of local life that was considered to be in accordance with the most dominant religion in Indonesia, Islam. Jones (2010) called this trend "Islamic pop." In this view, Islam was not only interpreted to be the means of spiritual guidance; it also came to be regarded as a symbolic commodity that was closely related to the demands, desires, and needs of the middle-class lifestyle.

The science and education sector also followed the same trend. Indonesia's Moslem population, encouraged by the success of Imam Khomeini in overthrowing the West-backed Iranian Shah, turned the Iranian revolution into a reference model for future development. Thus, many Islamic educational institutions began to 'improve' themselves and attempted to influence their educational institutions to embrace a form of modern education that was based on Islamic values. The symbols of Islam expressed in the clothing patterns of the Moslems (for instance, the hijab) have also become symbolic of modern society in Indonesia.

Unfortunately, this pop form of Islam operates only at a symbolic level and its growth is driven primarily by middle-class consumerism. The spirit of change, the reflection of the material acquisition, and the understanding of religious spirituality are marginalized and even ignored (Utama, 2015).

\section{Conclusion}

First, scientific education and research represent a sector that finds place in the priority-list of Indonesia's national development plan. However, the differential weightage given to particular sectors on the basis of the preferences, knowledge, and interests of specific leaders is a critical condition that must be fixed. Such modifications have especially been witnessed in Indonesia in the changes instituted by the Old Order and the New Order.

Second, the post-reformation era has brought a euphoria of freedom to Indonesia, where the anti-western paradigm still prevails. Consequently, the acculturation of Western values, the primacy of Islam, and the reappraisal of Indonesian values are manifested in the form of pop Islam, which is the current trend and lifestyle. Unfortunately, this form of Islamic vigor is spurred merely by the prestige of middle-class consumerism toward Islamic symbols without any real dynamism to drive change toward better conditions.

Third, the pattern of national development changed from a focus on the economy to a decentralized attention on contemporary issues. Nevertheless, the theme of development has not altered and it remains motivated by the mere improvement and revision of previous administrative decisions and errors.

Finally, neither the public nor the government regard the R\&D sector to be a priority. The government ceded its control over development priorities to the public because of the increased decentralization of the postreformation era. However, this reorganization resulted in development priorities being influenced by people's consumeristic tendencies.

As a closing statement, it is hoped that the findings of this study will first lead researchers to be willing to conduct studies on the management strategy of basic, intermediate, or advanced education. Such research projects should be aimed at stimulating the desire of Indonesian students to acquire an innovative thought process that is grounded on a scientific approach aligned to Indonesian norms and culture. Second, the results of this investigation will hopefully cause the Indonesian government to consider self-correction through the institution of a review of its contemporary national development priorities vis-à-vis its long-term national development plan.

\section{References}

AusAID (2011). Design document: Revitalizing Indonesia's Knowledge Sector for development policy. Australian Agency for International Development.

Bappenas (2004). Permasalahn dan Agenda pembangunan nasional 2004-2009. Jakarta: Bappenas.

Bidwell, C. E. (2006). Varieties of institutional theory: Traditions and prospects for educational research. In H.-D. Meyer \& B. Rowan (Eds.), The institutionalism in education (pp. 39-46). New York: State University of New York.

Boeke, J. (1954). Economics and economic policy of dual societies as exemplified by Indonesia. New York: International Secretariat, Institute of Pacific Relations.

Dhani, A. (2017, March 15). Article. Retrieved from tirto.id official website. Retrieved from https://tirto.id/jumlah-doktordi-indonesia-tak-sebanding-jumlah-penduduknya-ckK9. Tirto. ID 
Dikti, R. (2016, September 15). Anggaran Riset Indonesia Paling Buntut di ASEAN. Retrieved from http://risbang.ristekdikti.go.id/admin/media/Poskota-20160915-1.pdf

Furnivall, J. (1948). Colonial policy and practice: A comparative study of Burma and Netherlands. Cambridge: Cambridge University Press.

GBGI (2015). Global business Guide, Indonesia: Education. Global Business Guide, Indonesia official website. Retrieved from

http://www.gbgindonesia.com/en/education/article/2015/making_research_andamp_development_part_of_indones ia_s_vision_for_growth_11164.php

Janssen, W. Alternative funding mechanism: How changes in the public sector affect agricultural research. Retrieved from http://citeseerx.ist.psu.edu/viewdoc/download?doi=10.1.1.203.1000\&rep=rep1\&type=pdf. Chapter 8

Jones, C. (2010). Materializing piety: Gendered anxieties about faithful consumption in contemporary urban Indonesia. American Ethnologist, 37(4), 617-637. doi: 10.1111/j.1548-1425.2010.01275.x.

Kementerian Pendidikan dan Kebudayaan. (2015). Rencana Strategis Kementerian Pendidikan dan kebudayaan 2015-2019. Kementerian Pendidikan dan Kebudayaan.

Kementerian Perencanaan Pembangunan Nasional / BAPPENAS. (2010). Peraturan Presiden Republik Indonesia Nomor 5 tahun 2010 tentang Rencana Pembangunan NasionalJangka Menengah Nasional (RPJMN) Tahun 2010-2014. Jakarta: Kementerian Perencanaan Pembangunan Nasional / BAPPENAS.

Kementerian Perencanaan Pembangunan Nsional/Bappenas. (2014). Rencana Pembangunan Jangka Menengah Nasional 2015-2019. Jakarta: BAPPENAS.

Kementrian Keuangan Direktorat Jendral Anggaran. (2015). Pokok-Pokok Proses Penyusunan Anggaran Belanja Kementerian Negara/Lembaga. Jakarta: Direktorat Penyusunan APBN,Direktorat Jenderal Anggaran, Kementerian Keuangan.

Kementrian Riset, Teknologi dan Pendidikan Tinggi. (2015). Rencana Strategis Kementrian Riset, Teknologi dan Pendidikan Tinggi tahun 2015-2019. Jakarta: Kementrian Riset, Teknologi dan Pendidikan Tinggi. Retrieved from https://luk.staff.ugm.ac.id/atur/Permenristekdikti13-2015RenstraKemenristekdikti2015-19Lengkap.pdf

Maass, G. (2003). Funding of public Research and Development: Trends and changes. OECD Journal on Budgetin, IV(III), 41-69. Retrieved from https://www.oecd.org/gov/budgeting/43494478.pdf

MPR. (1998). Ketetapan Majelis Permusyawaratan Rakyat Republik Indonesia Nomor: ii/mpr/1998 tentang Garis-Garis Besar Haluan Negara. Jakarta: Majelis Permusayawaratan Rakyat.

Neelakantan, V. (2017). Science, public health and nation-building in Soekarno-era Indonesia. Cambridge Scholars Publishing.

Organization for Economic Co-Operation and Development (2010). OECD science, technology and industry Outlook 2010. Retrieved from https://www.oecd.org/sti/inno/46664553.pdf. OECD

Payne, A. A., \& Siow, A. (2000). Does federal research funding increase university research output? Retrieved from http://homes.chass.utoronto.ca/ siow/papers/research.pdf. Advances in Economic Analysis and Policy, 3(1). doi: $\underline{10.2202 / 1538-0637.1018}$

Sairin, S. (2011). Modernization and westernization: A never-ending discourse in Indonesia. Journal of Government and Development, 1-7.

SalaryEplorer (2017). Salary Explorer: Teaching and education. Retrieved from Salary Explorer Official website. Retrieved from http://www.salaryexplorer.com/salary-survey.php?job=50\&jobtype=1

Sharmin, S. (2010). The colonized mind: A study of postcolonial realities in selected modern fiction [BRAC University Thesis].

SJR (2016). Scimago. Journal \& Country Rank Scimagojr official website. Retrieved from http://www.scimagojr.com/countryrank.php?region=Asiatic\%20Region

Strehl, F., Reisinger, S., \& Kalatschan, M. (2006). Funding Systems and their Effect on Higher Education System; country Study-Austria. International OECD (IMHE study).

Tahmooresnejad, L., \& Beaudry, C. (2015). Does Government funding have the same impact on academic publications and patents? The case of nanotechnology in Canada. International Journal of Innovation Management. Retrieved from https://publications.polymtl.ca/2315/1/2015_Tahmooresnejad_Government_funding_same_impact_academic.pdf, 19(3). doi: $10.1142 / \mathrm{S} 1363919615400010$

The World Bank (2015). World Development Indicators. Science and Technology. Retrieved from http://wdi.worldbank.org/table/5.13

The World Bank (2016). Data. Retrieved from The World Bank Official Website. Retrieved from https://data.worldbank.org/data-catalog/GDP-ranking-table. World Bank

Utama, W. S. (2015). Incorporating spirituality and market: Islamic sharia business and religious life in post-new order Indonesia. Masyarakat: Jurnal Sosiologi, 20(2), 113-137. doi: 10.7454/mjs.v20i2.4798.

Yazid, M. N. (2014). The Indonesian economic development after 1965: Developmental state, radical politics and regional cooperation. SOP transaction economic research, IV(3). 